\title{
EMPATHY, NOT TRUTH: CAN A DIALECTICAL AND SKEPTICAL ARGUMENTATION ENHANCE BOTH DEMOCRACY AND HUMAN RIGHTS COURTS?
}

\author{
Alberto Puppo \\ Instituto Tecnológico Autónomo de México (ITAM) \\ Law School \\ apuppo@itam.mx
}

SUMMARY: Who is the best moral reasoner, the judge or the legislator? The aim of this paper is to refine this question, by distinguishing between different metaethical assumptions. If the meta-ethical assumptions of arguers are incompatible or if their institutional goal is to establish some truth, there is no way of entering into a constructive argumentative activity. My claim is that only when arguers renounce any epistemic temptation and feel empathy with respect to others' arguments, can institutions improve the quality of their judicial and democratic arguments, and therefore gain authority.

KEY WORDS: meta-ethics, emotions, judicial reasoning, moral judgments, prescriptivism

RESUMEN: ¿Quién es el mejor razonador moral? ¿El juez o el legislador? El propósito de este trabajo es refinar esta pregunta distinguiendo entre diferentes asunciones metaéticas. Si las asunciones metaéticas de los que construyen argumentos morales son incompatibles o si su objetivo institucional consiste en establecer algún tipo de verdad, de ninguna forma podrá generarse una actividad argumentativa constructiva. Mi tesis es que sólo cuando se renuncia a toda pretensión epistémica y se desarrolla empatía respecto de los argumentos de los demás, pueden las instituciones mejorar la calidad de sus argumentos tanto judiciales como democráticos, y por consiguiente incrementar su autoridad.

PALABRAS CLAVE: metaética, emociones, razonamiento judicial, juicios morales, prescriptivismo

Human lot. Whoever thinks more deeply knows that he is always wrong, whatever his acts and judgments.

Truth as Circe. Error has turned animals into men; might truth be capable of turning man into an animal again? 


\section{Introduction}

Human rights judges are often called upon to apply very indeterminate normative formulations, typical of the declarations of human rights, which incorporate moral values (such as dignity, liberty, etc.). As far as this task depends, at least partially, on some moral judgment, the question of what kind of moral reasoners they are seems to be central. In other words, if some moral issue is at stake, and the solution depends on a moral argument, it is legitimate to investigate how judges work as moral arguers. Even if the judicial format is still traditional, it is undeniable that beyond the appearance of a mechanical application of some evident (international) rules or principles, there is an authentic evaluation. Such an evaluation, because of the format, is often poorly understandable (van den Hoven 2011). That justifies the need for a deeper analysis of the judicial argumentation and of its implicit meta-theoretical assumptions. ${ }^{1}$

The starting point of this work is a question formulated by Jeremy Waldron (2009a): once we accept that judges are moral reasoners, what kind of moral reasoners are they? And, more importantly, are they better at moral reasoning than legislators? The main target of Waldron's work probably was Dworkin's claim — defended in his A Matter of Principle (1985) - according to which, in Waldron's words, "[t]o those who raise moral issues about their own or others" rights, the courts offer a forum in which [...] citizens are assured that these claims will be steadily and seriously considered" (2009a, p. 3).

The question is probably too broad, because the category of "courts" includes ordinary judges, constitutional judges, international judges, and so on. The judge Dworkin is referring to is the U.S. Supreme Court, or any domestic Supreme Court, institutions created in order to guarantee respect for a democratic Constitution and/or equilibrium between domestic constitutional powers. It is very difficult to translate the Waldron/Dworkin debate beyond the frontiers of the U.S., or its domestic law. ${ }^{2}$ Nevertheless, the question posited

\footnotetext{
${ }^{1}$ Works analyzing judicial argumentation are almost uncountable, and some of them are particularly profound and well argued. One of the reasons for the present work is that even one of the finest analyses (Feteris 2016) seems to underestimate, in general, the role played by moral - at least: not consequentialist- arguments.

${ }^{2}$ For that reason, I will not take Dworkin's theory "seriously": not because the theory itself is not relevant, but because it does not intend to explain, or to prescribe, how international Courts work or have to work. I thank an anonymous reviewer for having pointed out the curious absence of Dworkin in my work and, consequently, the need to explain my choice.
} 
is still fundamental, despite the fact that the arguments advanced are not really useful outside the institutional limits of U.S. domestic law.

The goal of institutions involved is relevant not only to clarify the reasons that support the choice of a given argument, but, above all, to develop some hypothesis about the status of the argumentative premises themselves. ${ }^{3}$ Are they certainties or just beliefs on moral issues? ${ }^{4}$ The weight of a moral argument depends significantly on the meta-ethical assumption adopted by the arguers. ${ }^{5}$ In my opinion, the debate generated by Waldron shows the lack of analysis of the status of moral arguments in judicial and legislative reasoning. At the end, the question posited - who is the best moral reasoner? - opens onto an essentially ideological scenario, and not a genuine assessment of moral arguments.

Waldron argued that legislators are better moral reasoners than judges, on the basis of a set of arguments that it is not necessary to recall here. The reason for that is that, even if we consider his argument plausible, the question itself is problematic. One criticism of Waldron's argument pointed out the importance of the institutional context (Dyzenhaus 2009). We cannot speak of judges and legislators as if they were some sorts of eternal substance. ${ }^{6}$ If we are really interested in the question he formulated, we first have to define the institutional context and the goal of the moral arguments. Actually, in his rejoinder, Waldron plainly recognized the virtue of such criticism, and the need for refining the question:

${ }^{3}$ On the importance of goals in order to understand an argument, and, specifically, on the distinction between intrinsic and extrinsic goals, and a typology of the latter, see Mohammed 2016.

${ }^{4}$ On the distinction between moral certainties and mere moral beliefs, see De Mesel 2016.

${ }^{5}$ The importance attributed, in this paper, to meta-ethical questions represents another reason for not including Dworkin in the picture, to the extent that he denied the distinction itself between ethics and meta-ethics. In one of his last works (2011), after having sarcastically reconstructed the traditional distinction, he clearly affirms that "[a] substantive theory of value must include, not wait for, a theory of truth in value" (p. 24), and finally rejects "the idea of an external, meta-ethical inspection of moral truth" (p. 25). Of course, I do not wish to claim that Dworkin, on this point, is wrong; I would simply accept that, if he is right, the main idea of this paper would be meaningless. I hope, therefore, that my argument will be assessed and criticized by scholars that do not agree with him, and suppose that it will be ignored or radically condemned — as a naive mistake - by Dworkinians.

${ }^{6}$ For an emphatic criticism against the monolithic trend, see da Silva 2013, pp. 558-560. 
[T] he institutional context in which legislative decisions are made includes the operation and activity of courts (sometimes their projected activity, as legislators seek to anticipate their response, and sometimes their earlier activity, as legislative debate may be triggered or affected by prior adverse court rulings). These interconnections [...] need to be taken into account in my question. (Waldron 2009b, p. 71)

Another criticism pointed to his uncritical acceptance of a premise: that reasoning in human rights matters is essentially different from in other matters, "that decisions about rights require a sort of moral competence that other political decisions - which we are quite happy to leave with the legislature- do not" (Waldron 2009b, p. 71). Waldron is "very happy to acknowledge this point" (p. 71).

Both criticisms show, in my opinion, a useful way of questioning the relationship between regional human rights courts (henceforth, RHRCs) and democracy. As such a question is meaningless if we do not refine it, there is a high risk that many theses on this topic -indeed pretty sophisticated ones - are missing the point by being too general. ${ }^{8}$

The refinement of the question can take the path of a comparative study of democratic and judicial institutions. This is not my objective here: I prefer to take a step back, and focus my attention on what constitutes a meta-theoretical starting point for a finer analysis of institutional argumentative interactions. I hope this analysis could be useful for legal comparatist scholars as well as for theorists of argumentation focused on the "opening stage" of a critical discussion, the stage "in which the protagonist and the antagonist of a standpoint at issue in the difference of opinion determine their zone of agreement as far as common procedural and material starting points (or 'concessions') are concerned" (van Eemeren et al. 2012, pp. 35-36).

For this reason, to illustrate such need of refinement, I will not study many cases of interactions between democracy and RHRCs; instead of this, I will show how the same case can be reconstrued very differently depending on how moral reasoning and democratic decisions are understood according to different meta-ethics and theories of democracy. ${ }^{9}$

${ }^{7}$ Waldron is referring to Sadurski 2009.

${ }^{8}$ A similar criticism is formulated by Gonzalez Bertomeu (2011).

${ }^{9}$ I suspect that there are almost unlimited plausible reconstructions. Plausibility will probably depend on the emphasis observers put, in good or bad faith, on some explanatory factor. See, e.g., Landemore and Mercier 2012. 
So I will briefly present, in the next section, the Gelman case, ${ }^{10}$ decided in 2011 by the Inter-American Court of Human Rights (IACHR from herein); this case involves five relevant participants: the Uruguayan people, national criminal judges, the national Supreme Court, the national legislator and (obviously) the IACHR, whose interaction is extremely helpful in understanding how a moral question can be differently approached.

Given that IACHR seems to have assumed that it was a better reasoner than the national democratic body, because of its rationality as opposed to the emotivism of the latter, it is necessary to go further and to wonder if both actors are doing the same or whether they are moving in completely different fields. In section 3 , I will refine the framework originally drawn by Waldron, by defining in what sense democratic bodies and human rights judges can be conceived as playing the same game, and therefore to what extent their argumentative moves can be part of the same dialogue type, ${ }^{11}$ and potentially of a genuine critical discussion. ${ }^{12}$

Once accepted that they are both moral reasoners, and that in the Uruguayan popular deliberation emotions have certainly played a significant role, I will analyze, in section 4, the possible roles played by emotions in judicial moral reasoning; if emotions play a role in judicial moral reasoning, the reason for preferring the Court ruling cannot be that it is completely emotion-free. As the concept of emotion is controversial, ${ }^{13}$ I will assume a somewhat trivial - and certainly theoretically deficient - definition: emotions are instinctive states of mind or feelings. ${ }^{14}$

Finally, in section 5, I will sketch out how the interaction between RHRCs and national democracies could generate an enhancing or a threatening effect, for the argumentation itself as well as for the institutions involved in it.

${ }^{10}$ Gelman v. Uruguay, Merits and Reparations, Judgment, Inter-Am. C.t. H.R. (ser. C) No. 221 (Feb. 24, 2011).

${ }^{11}$ According to Mohammed (2016), the dialogue type is defined by the goal of the argumentative interaction.

${ }^{12}$ Van Eemeren et al. (2012) cite several different models of critical discussion, but a necessary condition is surely that the protagonist and the antagonist are engaged in the same dialogue type.

${ }^{13}$ For an overview, see Cowie et al. 2011.

${ }^{14}$ I fully agree with Gilbert (2004, p. 247) when he says: "Whatever emotions are, we are all too aware of their presence in argumentative contexts, and whether they are sensations, feelings or some other psycho-philosophical entity is beside the point." 
My thesis is that if emotions are not conceived as the key to access to some moral or political truth, but in terms of the empathy necessary to imagine how other people feel and finally to increase the understanding of arguments constructed in hard cases, the interaction could be successful in producing better arguments and thus better decisions; not necessarily true answers, but more reasonable - and therefore acceptable - answers, all things considered.

\section{The Gelman Case}

The infamous case is about people who disappeared during Latin American dictatorships, but its originality derives from the multiplicity of conflicting decisions that I will try to summarize here. ${ }^{15}$

After the end of the military dictatorship in 1985, the new civilian government ratified the American Convention on Human Rights. A year later, however, it enacted an Amnesty Law (the Law No. 15.848) granting amnesty to members and agents of the dictatorship guilty of human rights violations. According to Gargarella (2015), the Uruguayan Congress was at that moment a democratically elected Congress with enough legitimacy based on voter's intentions to be able to assert that the Amnesty Law had a democratic consensus. In 1988, the Supreme Court of Justice confirmed the constitutionality of the Amnesty Law and one year later, by a national referendum, the electorate voted to retain the Amnesty Law. In 2000, a Commission for Peace was created to receive, analyse, classify, and compile information about the forced disappearances that occurred during the dictatorship. In 2003 a Criminal Court, on the basis of the Amnesty Law, dismissed a case introduced by Mr. Gelman, who therefore asked the Supreme Court of Justice to declare portions of the Amnesty Law unconstitutional; the Court denied his claim in 2004. The Gelman case gained considerable notoriety, to the extent that President Tabaré Vázquez, one year later, in his inaugural speech took a firm position on it: the Gelman case was excluded from the scope of the Amnesty Law. In 2009, the Supreme Court of Justice declared portions of the Amnesty Law unconstitutional, but a few days later, for the second time, the Uruguayan people voted in favor of it.

${ }^{15}$ For a complete chronology, see: <https://iachr.lls.edu/sites/iachr.lls.edu/files/ iachr/Cases/Gelman_v_Uruguay/tripodes_gelman_v._uruguay.pdf $>$ [consulted: 23/ $03 / 2018]$. For an analysis extremely relevant of the question at stake in this article, see Gargarella 2015. 
The popular scrutiny has been preceded by a strong social deliberation, a "complex, tense, confrontational but in any case a deliberate process of collective reflection" (Gargarella 2015, p. 6). Disregarding this strongly democratic circumstance, the IACHR essentially applied its own precedent, established in the Barrios Altos case, ${ }^{16}$ and declared the incompatibility of Uruguayan Amnesty Law with the protection of Human Rights resulting from the American Convention.

But history did not end here. The Uruguayan legislature, to comply with the IACHR ruling, passed Law 18831, which effectively repealed the Amnesty Law. Despite that, the Supreme Court, in 2013, declared the unconstitutionality of Law 18831 for violating the principle of legality, because it had the effect of a retroactive criminal law. Finally, the same year, the IACHR, ${ }^{17}$ in the context of a supervising decision, noted that despite the clear will of the Uruguayan legislative and executive powers, the Supreme Court decision constituted a failure in compliance with its previous decision.

The question at stake is not if the Amnesty Law is good or bad; the question is about the reasons the IACHR had for not attaching importance to the Uruguayan popular vote. Gargarella (2015, p. 6) suggests that the Court's reasoning implicitly assumed that majority decisions are essentially irrational and judges' decisions, on the contrary, are essentially rational, and therefore have to prevail, without the necessity of further arguments.

This means that the IACHR does not recognise the democratic body as a legitimate opponent in a critical discussion, democratic arguments do not deserve a critical assessment; so the Court does not even enter into the argumentation stage. This posture can be described by saying that, from the Court's point of view, "it makes no sense having an argumentative exchange" (van Eemeren et al. 2012, p. 42); if the opening stage is a failure, there is no reason for entering in the argumentative stage.

Given this premise, what are the possible outcomes for both the Regional Court and Uruguayan democracy? In a separate opinion, Inter-American judge Mac-Gregor ${ }^{18}$ argued that the Uruguayan Supreme Court decision threatened the effectiveness of the InterAmerican system. That seems plausible, but not more plausible than

${ }^{16}$ Barrios Altos v. Peru, Merit, Judgment, Inter-Am. Ct. H.R. (ser. C) No. 221 (March 14, 2001).

${ }^{17}$ Gelman v. Uruguay, Monitoring Compliance with Judgment (March 20, 2013).

${ }^{18}$ Gelman v. Uruguay, Monitoring Compliance with Judgment, Separate Opinion of Judge Eduardo Ferrer Mac-Gregor Poisot (March 20, 2013). 
the speculative claim according to which the IACHR ruling threatened the effectiveness of Uruguayan democracy. To the extent that one possible interpretation of the Gelman case is that the interaction between human rights courts and democracy generates a threat to the authority of both, this case represents a perfect starting point for refining the question at stake.

The moral/political question at stake is two-fold: a substantive and, apparently, legal one, and a question of moral argumentative competence. The substantive question is whether there is a moral and/or political reason for not judging some very odious crimes of the past. I am assuming that it is a moral question. It does not matter that many legal sources have been invoked by the IACHR; even accepting that, such sources are vague enough to give decisionmakers a huge space for moral reasoning.

The question about moral competence is about who is best placed to give an answer to the substantive question. If there is a right answer, the question is: who is (the most) capable of finding it out, that is, who is the best epistemic arguer? If there is no right answer - or if there are no accessible means for discovering it - the question is: who has the legitimacy to make a potentially wrong decision, or a decision whose potential wrongness would have the lesser cost?

The central issue is: what does it mean that a substantive moral question has, or not, a right answer? Does it mean that there is a moral truth and that the answer is right if it can be deduced from it? Or, more modestly, does it mean that some answer is justified on the basis of a good (or at least reasonable) moral argument without implying the existence of some moral truth?

The aim of this paper is to show that the understanding of, and the answers to, these questions depend, at least partially, on the role that truth and emotions play in judicial moral reasoning and in the constitution of the democratic game. According to Gargarella's interpretation, it seems that the preference the IACHR gave to its own precedent depended on a particular form of rationality: a popular vote is not rational because it is affected (infected?) by emotions, and is therefore not trustworthy. Such a belief seems to be a typical expression of "the now-desiccated tradition" assuming a strong emotions/rationality opposition (Sajó 2010, pp. 355-357). Such a tradition was also relevant in the multi-disciplinary area of Argumentation Theory. As strongly stated by Gilbert (2004, p. 247), beyond all the controversies between the theorists of argumentation, there was one "area of concurrence": "the importance of rationality, and the irrel- 
evance, or even the fallaciousness, of emotional considerations put forth in an argument". ${ }^{19}$

\section{Refining the Analytical Framework: the Best Reasoner, the Best} Moral Reasoner or the Best Meta-Ethic?

Are legislative bodies and human rights judges doing the same thing? Are they playing the same game? If they are not, then the question is not which one is the best moral reasoner, but which game is the best. Someone will prefer democratic legislation; others will prefer human rights adjudication. The IAHRC seems to assume that it is not the same game: its game is a rational one, while the popular democratic game is an emotive one. Such a position expresses a traditional opposition between reason and emotions that deserves further analysis.

So the first assumption, for making the comparison meaningful, is that they do the same thing, they play the same game. But, what is the point of the game called moral reasoning? Is it the discovering of some moral fact? Is it the production of some moral prescription? Is it the expression of emotions? Does the truth have some relevance? Traditionally these questions have occupied the meta-ethical debate; a positive answer to the first question is called descriptivism, to the second is called prescriptivism and to the third is called expressivism or emotivism. ${ }^{20}$

Disagreement on the question of who is the better moral reasoner can be the consequence of a disagreement on what is the point of moral reasoning. For example, one can believe that judges are better at discovering moral facts, but that a democratic body is better at formulating moral prescriptions, and so on. In that case, both claims would miss the point, because they are not speaking the same language: moral arguers would not be engaged in the same dialogue.

In some way, moral theories and theories of democracy have lived in parallels worlds. But when a hard case makes a confrontation unavoidable, on the same moral question, between a democratic body

${ }^{19}$ Gilbert (2004, p. 248) clarifies his point recalling that the pragma-dialectic trend in argumentation theory, represented for instance by van Eemeren et al. 2012 , does not exclude affective components. That is, the pragma-dialectic theory seems to recognise that "[e]motion, in all its forms, is an integral part of human communication, and, consequently, of human argumentation".

${ }^{20} \mathrm{I}$ do not include, in this picture, constructivism because it does not fit with a clear distinction between descriptivism and non-descriptivism. I will return to that in section 4 . 
and a regional human rights Court, the need to construct a common language - that enables us to define a common framework - arises.

Such common language presupposes that people using it do agree on the nature of moral reasoning and on the role played by moral reasoning in democracy and judicial decision-making. Such a presupposition is not obvious at all.

When such an issue arises in the context of legal institutions (judicial or legislative), the first point on which agreement is necessary is that the conclusion of an institutional reasoning is a prescription; its conclusion is that something is forbidden, permitted or obligatory.

The disagreement comes from the argumentative justification of such a prescription. Is conduct A forbidden because it is morally wrong, or is it forbidden just because the majority has taken such a decision? Is the decision of the majority based on the knowledge of the moral wrongness of such conduct?

If a judge forbids conduct A because it is a moral truth that A is morally wrong, and the legislator does not forbid it because it is a moral truth that A is not morally wrong, then one of them is making a mistake.

It is possible that the means for discovering moral facts are not the same - that is that the truth-conditions of moral judgments are not the same - but in this case both would be assuming some form of moral descriptivism.

If, on the contrary, both the democratic body and the Court do not pretend to establish some moral truth, then there is no place for mistakes; but there is still a relevant space for judging their respective arguments to be more or less justified. In plain words: the rejection of truth in moral issues does not mean that every moral conclusion is equivalent. There is a space for argumentation in which someone can win the battle, not because the truth is on her side, but because her argument sounds better than others.

In the Gelman case, for instance, one can consider that the prescription formulated by the legislator - and confirmed by the people - failed because it did not take into account the victims' need for truth, or that the prescription formulated by judges failed because it did not take into account the need for social reconciliation or the weight of democratic deliberation, and so on.

All this is contingent, in the sense that for any conflict between a democratic decision and a judicial decision, the meta-ethical assumptions of the institutions involved may or may not be descriptivist. Moreover, normally the institutions involved are not clear about their meta-ethical assumptions. 
My first point here is that depending on the meta-ethical postures, the understanding of democratic and judicial moral arguments changes. My final thesis will be that according to a non-descriptivist meta-ethics both moral reasoners can enhance their argumentative performances, and therefore their moral authority. ${ }^{21}$

\section{Emotions and Truth in Moral Reasoning}

It is hardly contestable that emotions play a relevant role in all social practices, including judicial and democratic decision-making. But the mainstream view is (or has been for a long time), from a normative perspective, that emotions should not play any role in adjudication and are dangerous in democracy (Marcus 2012, pp. 131-132).

Nevertheless the trend is changing, given that, on one hand, the role that emotions can play in rational processes -in empirical terms - seems to be much more important than what the mainstream conception thought; and, on the other, such a role is not perceived as necessarily bad. Without claiming that "emotional messages are either as clear as logical messages or almost so" (Gilbert 2004, p. 248), it is more than plausible that emotions - particularly empathy - could contribute, in moral reasoning as well as in democratic processes, to better arguments and therefore better decisions. ${ }^{22}$

${ }^{21}$ An anonymous reviewer suggested that my deflationary approach is more convincing if referred to the reasons for having an RHRC than if referred to the binding character of its rulings. I understand the point but I think that the binding character of a holding does not need a specific moral justification as far as it results from the legal source having instituted the court — and in most cases from some domestic constitutional provisions. What can become problematic is not the duty to comply with a given ruling, but the moral legitimacy of the court itself. Of course, these dimensions are connected to the extent that the meta-ethical assumptions implicit in the moral arguments used to justify a binding decision are plausibly the same ones that the court assumes for justifying its legal authority (and existence). In plain words: if someone thinks that a given decision is morally good and that the court that made it is also morally good, it is plausible to think that she is using the moral term "good" with one and the same meaning, that is, that she is assuming the same meta-ethical posture.

${ }^{22}$ As the literature is huge, I just mention a recent representative work (Fleming 2012), the first part of which is dedicated to moral judgments and the second to democratic politics. See too Sajo 2010 and Sajó 2015, remarkable works to the extent that its author is a judge of the European Court of Human Rights. Even if I do not borrow his terminology, I find his distinction between public sentiment and moral emotions very insightful, to the extent that it reflects how emotions play in the political and the moral game. It does not mean that emotions are different but that their social expression depends on several factors, the first of which is the collective feature of public sentiment and the substantially private character of moral 
If we take Emily Kidd White's claim seriously (2014), we can argue that when RHRCs are dealing with evaluative concepts, for example dignity, emotions are a key tool for reaching legal solutions. The real question is about how to best reconstruct the way moral reasoners construct their arguments and reach their decisions based on emotions. ${ }^{23}$

Even if the classical meta-ethical distinction is between descriptivist and non-descriptivist theories, ${ }^{24}$ the role attributed to emotions could suggest new criteria for grouping conceptions, alternative to the traditional way, exclusively focused on truth; and, above all, I think such an approach could help us to analyze how (virtuous or vicious) the interaction between democracy and RHRCs could be.

I will outline four possible connections of emotions to moral reasoning, and particularly to the possibility of moral truths: (1) emotions are the natural truth-conditions of moral judgment; (2) emotions are just emotions, they are not related to moral truths; (3) emotions are necessary to have imagination, therefore indirectly for making general (universalizable) prescriptions; (4) emotions are necessary to have moral intuitions, therefore indirectly for accessing the non-natural truth-conditions of moral judgments.

\subsection{Emotions as Natural Truth-Conditions of Moral Judgements}

Emotions can play a role in moral reasoning as natural properties, which work as truth conditions for moral judgments. ${ }^{25}$ The problem with this approach is that, depending on our individual emotive experience, we will judge something as morally right or wrong; such a subjective approach seems to be completely useless if our intention

judgments. A Constitution, as a matter of principle and as a political expression, is clearly the locus in which both dimensions interplay. Such interplay is described as follows: "Moral emotions lend to public sentiments the power that enables those sentiments to shape constitutions and other legal institutions" (2015, p. 46).

${ }^{23}$ Such relevance of emotions in the construction of arguments based on pathos can be extended to the whole domain of constitutional decisions. According to Greene 2013, this makes constitutional law an essentially persuasive practice and therefore a form of politics.

${ }^{24}$ In order to avoid superfluous bibliographical references, for a clear reconstruction of the different meta-ethical postures, see Nino 1984, chap. VII. On the descriptive side, see also Broad 1930, chap. VII, where the ethical theories of five great moral philosophers (Spinoza, Butler, Hume, Kant, and Sidgwick) are analyzed and classified on the basis of the same schema used by Nino: naturalistic/non-naturalistic and subjective/objective.

${ }^{25}$ See, at least, Damasio 1999, and with a specific reference to morality and decision-making, Nelissen et al. 2013; see too Marcus 2012. 
is to construct a public moral discourse able to reflect genuine moral disagreements. ${ }^{26}$ To avoid that, we have to move from the individual to the collective or majority level. If the majority feels a negative emotion, what provoked it is morally wrong. Such an explanation could be applied to both human rights adjudication and democracy.

In an RHRC, legal training has probably domesticated emotions, in such a way that judges can largely share some emotional attitude. In a democratic body, the diversity of emotional attitude is substantially higher. The majority rule can work as a channel for expressing emotions, particularly when people directly express their preferences. One could imagine that, for Uruguayans, the desire for peace or the feeling that the past is past and that the best attitude is to go forward was stronger than the emotion generated by the odious crimes perpetrated during the dictatorship. The Uruguayan popular vote probably expressed such dominance of a peaceful emotional attitude. But, the IACHR was moved by the opposite emotion, on the basis of a common trend in human rights rhetoric: no human can feel peace in the face of impunity.

The fact that the majority of judges experience a feeling of outrage means that this something is judged morally wrong, emotions being the truth-makers of such moral judgments. Among the premises of a human rights decision we could so identify a moral judgment that aims to describe some natural fact. The majority of judges shared the feeling that the Amnesty Law enacted by Uruguayan legislator was outrageous. The moral judgment worked as a premise in a reasoning whose legal conclusion was that the American Convention of Human Rights forbids the Amnesty Law.

Even if I used the word "majority", I am not unaware that this is completely vague. There is a common perception according to which human rights judges are (or have) an elitist power; in other words, they do not represent the majority. For my argument, the degree to which judges actually represent the majority is not relevant. Nonetheless, I must point out that such emotive naturalism could be understood as individualist, majoritarian or elitist. From an external point of view, most of the Court's members could be perceived as elite. So, according to such a conception the confrontation is between an elitist emotion and a majority emotion.

\footnotetext{
${ }^{26}$ The stronger criticism against any form of naturalism was probably formulated by Moore (1903).
} 


\subsection{Emotions without Truth: Moral Particularism at Work}

The same emotional framework could be used for providing an emotivist or expressivist reading. From this perspective, emotions are not natural properties working as truth conditions for moral judgments. A moral judgment expresses some emotion in order to provoke certain reactions; for example, in the Gelman case judges can express compassion towards the victims and at the same time try to provoke shame in the authors of the Amnesty Law. Obviously, I do not believe that this is what really occurred; I am only suggesting a possible emotivist or expressivist reading of the role played by moral judgments.

When we move to a judicial context, the problem is that this conception seems to lead to a radical particularist trend, ${ }^{27}$ in which judicial emotions (as far as they are not natural states) are essentially uncontrollable. If moral judgments play this role in human rights adjudication, the resulting picture will probably be what H.L.A Hart (1977) called "the nightmare".

A way to reduce particularism is to relativize the emotive or expressivist ingredient: moral judgments do express and provoke emotions but they do something else as well; they have a descriptive component that enables judges (and observers) to make inferences. A moral judgment would not be just a meaningless expression of approval or disapproval. It is likely that the most sophisticated version of this moderate version is the well-known prescriptivism elaborated by Richard M. Hare $(1952,1963)$.

\subsection{Emotions, Imagination and Universalizable Prescriptions}

According to Hare's prescriptivism, a moral judgment is (or expresses) a universalizable prescription. A moral judgment is not true or false, but its factual predicate allows the establishment of correct inferences; for example, if we affirm "impunity is bad", we can infer that, if we conventionally consider a certain amnesty law as subsumable under the general category of impunity, such acts are bad too: "In virtue of possessing this descriptive meaning moral judgments are universalizable" (Hare 1963, p. 21). To say that a moral judgment is a prescription means that when I say "the Amnesty Law is bad", what I really mean by that is "do not enact the Amnesty Law"

${ }^{27}$ Particularism is much more complex than its reconstruction provided by antiparticularism. The chief proponent of moral particularism is, probably, Dancy (2004). 
or that "the Amnesty Law has to be repealed" are universalizable prescriptions.

A key tool in order to formulate a moral judgment is the ability to imagine. We can imagine hypothetical cases or, more concretely, we can imagine that we occupy the place of someone facing a moral dilemma. Past experiences can be useful when trying to imagine something, but it is not necessary for someone to have experienced something in order to be sympathetic with someone else's moral situation (Hare 1963, p. 49).

Like any prescription, a moral judgment does not have truth conditions. But such a prescription is not just the expression of approval or disapproval. A moral judgment, even without aspiring to be the truth, aims to be rational. The test of universalizability guarantees such rationality. Only a universalizable prescription is a genuine moral judgment ${ }^{28}$ and, I would suggest, according to the pragmadialectical theory of argumentation, an acceptable argument in order to justify a legal decision. To universalize a prescription is probably a conditio sine qua non in order to comply with a dialectical obligation (van Eemeren 2012, p. 50).

But in order to universalize, we need imagination. It is precisely at the moment when we are governed by imagination that emotions could play a role. A judge, without some empathy for the parties, cannot imagine what their situation was really like. In an interesting sense, emotions are a part of rationality: we cannot be rational if we are incapable of feeling empathy for other people and putting ourselves in hypothetical moral situations. ${ }^{29}$

Because I myself feel rational, I start the universalizing enterprise. Whatever our conception of the relationship between universalizability, as a rational moral process, and emotions, it is plausible to conclude that emotions play a genetic role. What is the difference between prescriptivism, on one hand, and emotional naturalism or

${ }^{28}$ A criticism moral philosophers usually make regarding prescriptivism is that the goodness is in an important way something merely formal. A moral judgment is just a complex process, and we should accept that a fanatic Nazi can legitimately formulate the moral judgment (as a prescription) according to which non-Aryan people have to be exterminated. Actually if the fanatic imagines he is in a hypothetical situation in which he is not Aryan, he could still subscribe to the same prescription. See Fullinwider 1977. For an analysis and a criticism of Hare's attempt at solving this puzzle on the basis of "imaginative substitution", see Robinson 1981.

${ }^{29}$ On the complex meaning of empathy, as both an affective and cognitive state, and its relevance for legal interpretation, see Deight 2011. Another provocative way of putting that, as William James (1879) suggested, it is to say that there is a "sentiment of rationality". 
expressivism, on the other? First of all, according to my reading of prescriptivism, emotions are relevant as a starting point; we need them in order to imagine. But they do not determine our judgment. Emotions are necessary for a moral reasoner to be able to imagine, but it is more important that he is able to take some distance from emotions. Emotions play a cognitive role, not a normative or epistemic one. Emotions enable us to know what the relevant factual situations are in which a moral prescription makes sense, but they do not work as the truth conditions of such moral judgments.

Imagination is nourished by past experiences. In the Gelman case, the IACHR based its decision on a precedent, the Barrios Altos case ${ }^{30}$ However, according to Gargarella, the almost mechanical application of such precedent was proof of a surprising lack of imagination. ${ }^{31}$ In the first case, the Amnesty Law was a "self-amnesty" enacted by Peruvian legislators to guarantee their own (and Fujimori's) impunity. Not to see the difference between these two cases would be something like not seeing the difference between a murder and a suicide. The past experience gives to the IACHR a ready-to-use solution and inhibits a finer analysis of the case. Such fine analysis, by the way, seems not to be necessary if the democratic voice is considered as irrelevant, so that the only relevant property is the impunity issue. The conclusion, from the IACHR's point of view, is not wrong: the cases are identical.

The question here is not if the Barrios Altos and Gelman cases are identical or not. My point is just that emotions and imagination can help to see nuances. If empathy, in general, helps to understand other people, in a similar way, judicial empathy would help to understand the present case, its specificity and, potentially, to override a precedent or to change its ratio decidendi. ${ }^{32}$

According to a prescriptivist reconstruction of the Barrios Altos case, judges have not asserted some natural truth about the wrongness of the Amnesty Law. They formulated a prescription in order to guide the future conduct of States. Judges are supposed to imagine what the Amnesty Law means in the actual case, but they also have to imagine other hypothetical, similar but not identical, situations in

${ }^{30}$ Barrios Altos v. Peru, supra note 16.

${ }^{31}$ The IACHR ignored "an especially important factor in order to differentiate between amnesty laws: their different democratic legitimacy" (Gargarella 2015, p. 4).

${ }^{32}$ Empathy could have another dimension, towards judges having decided the past case; but in the Gelman case this would not be relevant, given that the same Court decided both the precedent and the present case. 
the future. ${ }^{33}$ They have to imagine future political situations in which impunity could be a controversial issue, for example a situation in which the Amnesty Law is not enacted by the perpetrator himself, as in the Barrios Altos case, but by a democratic body that, as in the Gelman case, after a genuine deliberative process, decides not to punish certain crimes.

So, the lack of imagination was probably the cause, in the first instance, of a too monolithic precedent, but, once confronted by a clearly different situation, the lack of empathy for the Uruguayan people was the cause that did not allow the IACHR to refine its precedent, taking into account, above all, the (political) consequences of its mechanical application. Another question —often a difficult one - is to know what consequences are bad or good, but this is not the point. The point is that the Court does not take the time to reflect upon consequences, and this fact can be considered, in a hard case, as a lack of argumentation.

Given that people can feel empathy in different circumstances and with respect to different people, moral reasoners improve their performance when they are not reasoning alone. What each judge feels can help other judges imagine further. But, as previously said, such improvement can be exiguous when people, in this case human rights judges, have been educated to feel similar emotions; or, radically, to deny that, as judges (even if not necessarily as human beings), they feel anything at all.

Another possible explanation is that human rights judges do not need to be sensitive to their emotions because they have direct access to moral truths. Their experience in human rights cases allows them to have the moral intuitions necessary to discover the right answer in each case. If this is the case, the meta-ethic implicit in their moral reasoning seems to be moral intuitionism. The question is now what role emotions can play in having such moral intuitions. A legal interpretation grounded on moral intuition necessarily denies any pragmatic dimension: no consequentialist argument can override some (argument grounded on a) moral truth.

\subsection{Emotions, Intuitions and the Discovering of Moral Truths}

Intuitionism is a descriptive non-naturalist theory claiming that human intuitions could perceive objective moral goodness as a (non-

\footnotetext{
${ }^{33}$ To think about future cases is a central moment in order to achieve stability. On this topic, see Puppo 2016.
} 
natural) property of some actions. ${ }^{34}$ The question here is if emotions could drive our moral intuitions. ${ }^{35}$

What is potentially common to both prescriptivism and intuitionism is that without emotions it is impossible, in the first case, to imagine hypothetical cases that are essential for the application of the universalizability test, and, in the second case, to recognize the intrinsic goodness of human actions. Nevertheless, while emotions in the first case just work for testing the universalizability of a moral prescription, without saying anything about moral truths, in the second case, emotions would be a tool for discovering moral truths. By assuming intuitionism, we can reconstruct the Gelman ruling by saying that the wrongness of the Amnesty Law was captured by the judges' moral intuitions. The judges were not prescribing that the Amnesty Law had to be forbidden; they were just describing a moral fact: the wrongness of the Amnesty Law and the goodness of the victims' complaints.

According to this conception, either the IACHR or the Uruguayan democratic body is making a mistake. If moral intuition is driven by emotions, it is plausible to think that one of them had the wrong emotions and, for that reason, the discovery of moral facts was biased. Emotions in that case are not, directly, the truth-conditions of a moral judgement; but an emotional error constitutes an obstacle for the discovery of moral objective properties.

What is the source of such a mistake? One possible answer is based on the origin of the emotions involved. Retaking what I said in the

${ }^{34}$ Intuitionist meta-ethics is usually attributed to Moore (1903), probably because it was he who developed the strongest and best articulated criticism against any form of naturalism. This does not mean that there were no intuitionists before him, as Moore himself recognized. Even so, the only moral philosopher Moore took seriously was Henry Sidgwick. This fact is very important to my argument, because Sidgwick can probably be considered as prescriptivist, as correctly pointed out by Stephen Darwall:

Since Moore credited Sidgwick with being the sole writer to have "clearly recognized and stated" good's indefinability as the fundamental fact of ethical philosophy [...], it may come as a surprise to find Sidgwick characterizing ethics' "fundamental notion" very differently, namely, as that "represented by the word 'ought' or 'right" ". For Sidgwick, the core feature of ethical judgments is their normativity, their entailing some " 'dictate' or 'precept' of reason to the persons to whom" they relate [...]. Ethical judgments assert normative reasons for actions and attitudes. (Darwall 2003, p. 469)

The references and notes omitted refer to Moore 1903 and Sidgwick 1901 [1874].

${ }^{35}$ See, for a deep analysis of the distinction between emotions and intuitions, as well as of their connection in moral and political decision-making, Bandes 2012. 
section dedicated to naturalism, it is plausible that the opposition is between an elitist emotion and a majority emotion. The same assumption pointed out by Gargarella can be used here: the IACHR thinks that its emotion is more rational than the others, so that the moral intuition driven by its emotion is the correct tool for discovering the right answer. Another explanation is that the IACHR's emotion is a universal emotion while any national democratic emotion, at best, just represents what a given political community feels.

The choice of one or another emotion is definitively a political choice. Once it is accepted that the human rights judges' moral reasoning is conceived, at least in the Gelman case, as overriding the democratic choice, the question at the origin of this paper is clearly on the table: is such overriding power threatening or enhancing democracy? The answer will depend, as I will try to show in the next section, not only on what kind of moral reasoners judges and democratic bodies are, but also on the conception of democracy that is assumed, and particularly what kind of political emotion is associated with democracy.

Depending on the political emotion that is supposed to support democracy, one or another meta-ethic can be more democracyfriendly. I think the real question is whether intuitionism or prescriptivism is the best candidate for incorporating moral reasoning in a constructive democratic game. Neither emotivism nor moral naturalism seems to be a successful candidate because it is somehow difficult to accept emotions as the unique criterion for reaching moral conclusions. My thesis will be that prescriptivism is the best option because it conceives moral judgements as the result of universalizable prescriptions formulated on the basis of an empathic imagination. Imagination is improved by emotional pluralism, so both human rights courts and democratic bodies can contribute to the making of better moral prescriptions. Intuitionism, on the other hand, as it is based on moral truth, would oblige us to choose the correct emotion: it is not possible that both the IACHR and the Uruguayan people are reasoning in a correct way; one of them is making a mistake, and assuming, in a very realist way, that no one would admit to being the wrong reasoner, there would be no room for a constructive and dialectical argumentation.

The picture sketched up until here is nonetheless incomplete; in the Gelman case judicial moral reasoning encounters and fights against the normative expression of a political community; the next step will necessarily be toward democracy as a political mechanism 
potentially conflicting with human rights protection: what about the political emotions assumed by (the conceptions of) political institutions and their potential relations with supranational judicial bodies?

My purpose here is not to develop a classical analysis of the potential conflict between democracies and supra-national human rights protection. Of course, the debate about theories of democracy will be present, as unavoidable background, but the focus will be on the role played by emotions when addressing such conflict. The connection between emotions and theories of democracy is provided by the notion of political truth. To what extent is the truth a key element in democracies? To what extent are emotions a key element to establish political truths? The following analysis will integrate the previous one concerning emotions and truth in moral reasoning, and will lead to a conclusion about the best combination of meta-ethical positions and theories of democracy in order to avoid any threatening effect for both RHRCs and national democracies.

\section{Communities of Feeling, the Truth and Human Rights Courts}

Mabel Berezin (2002) analyzes two main political emotions: the secure state and the communities of feeling; the latter "generate emotional energy in support of or against the polity", "they bring individuals together in a bounded, usually public, space for a discrete time period to express emotional energy" (Berezin 2002, p. 39). András Sajo describes the same phenomenon as crucial for the formation of the modern liberal constitutions:

By the late 17th and early 18th centuries, expressing sentiments of benevolence, compassion, pity, sympathy, and fellow-feeling became legitimate beyond the private sphere. Such expressions became more central to religion, literature, and politics and served as a source of social solidarity. (Sajó 2016, p. 46)

When such energy is produced by a form of ressentiment, ${ }^{36}$ as a consequence of a feeling of insecurity or deep injustice, it probably causes a redemptive force or a democratic promise (Arditi 2003), something that is usually central in populist theories as well as movements. But the same energy can also be controlled: modern liberal governments have to manage public — and potentially dangerous-

\footnotetext{
${ }^{36}$ See, on ressentiment as a key concept for understanding populisms, Demertzis 2006. See also Sajó 2016 (pp. 46-47), on the specific public (res)sentiment against political elites having contributed to the French Revolution.
} 
(communities of) emotions; as correctly stated by Sajó (2016, p. 47), "institutions of modern constitutionalism were created partly as tools of emotion management".

The community of feeling can be conceived in a strong or a weak way. The strong one assumes an epistemic conception of democracy and/or an intuitionist meta-ethic: the truth stands in the people and/or preexists in objective and universal values. The weak way is compatible with a skeptical proceduralist, or a minimalist epistemic conception, ${ }^{37}$ and the meta-ethic that it presupposes can be prescriptivism.

I will not analyze the strong populist version of the community of feeling because such political emotion, in the Gelman case, played no role. In this section I will focus, first, on the strong community of feeling represented by the descriptivist moral claim of the IACHR, and I will analyze its interaction with the Uruguayan democratic inclusive expression. I will argue that such interaction could lead to a threat both to IACHR and to democracy (1). Then I will reconstruct a different situation, based on the denial of moral or political truths, in order to show that such interaction could enhance both RCHRs and democracy (2).

\subsection{Inclusive Political Participation vs. Universal Values: the Threatening Effect}

A weak political expression of the community of feeling only insists on the need for a more inclusive participation. The feeling of political exclusion can be the consequence of an electoral democracy whose rules lead to an elitist government or, at least, a government that does not represent the interests of a large part of the population. The attack against proceduralism is above all against its representative and elitist side. The direct participation in the election of leaders or in the setting of political questions, for example by referendum, would be a satisfactory canalization of this community of feeling.

In the Gelman case, the people intervened two times, expressing its will, not against what the representative legislator decided, but in support of it. It is possible that the result of the popular vote is not conceived as the true answer, but just as the outcome of a democratic inclusive procedure. In that, contrary to a strong populist

${ }^{37}$ There is no space here to reconstruct democratic theories. For a set of clear definitions and a full assessment of minimalist, procedural, deliberative, epistemic and populist theories of democracy, see Saffon and Urbinati 2013; in this work, they propose a strong defense of procedural democracy. See too Greppi 2013. 
conception, no epistemic assumption is made: the people is not the sole possessor of the truth, but its political argument can claim some form of legitimacy.

Judicial review, in general, and especially its supra-national expression, is often conceived as a limitation of the national legislative power, eventually for protecting minorities whose voice is not reflected in the legislative body. If this is so, when a large participation makes a democracy more inclusive, any supra-national intervention seems to lack legitimacy.

A way to justify such interference would be on the basis of a lack of legitimacy affecting the popular vote. If voters are not really expressing their free will, an RHRC can protect people's political rights by opposing its veto to the outcome of the popular vote. It is, of course, an empirical question whether the people, in the Gelman case, were or not free. Another question is if the only way for legitimizing popular vote is the proof that it was preceded by a genuine deliberation.

In the Gelman case, the IACHR seems to believe that the fact of an inclusive popular participation has no weight at all if what is decided can reduce the force of some human right; ${ }^{38}$ the moral belief of Uruguayan people is irrelevant if it is incompatible with the moral certainty asserted by the Court itself; in other words, the moral argument developed by the people is not really moral. For that reason, it does not need to inquire about its deliberative character. Gargarella, by contrast, in his criticism of the IACHR decision, precisely insists on deliberation having preceded the popular vote. ${ }^{39}$

Assuming that this was not the case, there is still an argument supporting the majority vote: the mere fact of being a majority decision has some virtues. The theory of democracy defended by Landemore is epistemic, but she does not base the epistemic force of democracy on procedures, as Estlund (2008) did, and even less, on deliberation, as Nino (1996) did. The interesting move of Landemore is to argue that a more inclusive vote not only produces fairer decisions but also

\footnotetext{
${ }^{38}$ See Gelman v. Uruguay, Merits and Reparations, cit., par. 238: "The fact that the Expiry Law of the State has been approved in a democratic regime and yet ratified or supported by the public, on two occasions, namely, through the exercise of direct democracy, does not automatically or by itself grant legitimacy under International Law"; and par. 239: "the protection of human rights constitutes an impassable limit to the rule of the majority".

${ }^{39}$ See Gargarella 2015, pp. 5-6, and footnote 7.
} 
smarter decisions. ${ }^{40}$ Even renouncing the idea that the initial moral question has a right answer, a more inclusive vote is a good criterion for maximizing "our collective chances to make the right choices" (Landemore 2012a, p. 3), even if it does not avoid mistakes.

According to Landemore's conception, I guess, no judicial argument invoking a lack of deliberation and, hence, of legitimacy could have been opposed to the virtues of number. The only way for justifying the distrust in the outcome of Uruguayan popular vote is a strong descriptivist assumption: the outcome is wrong, whatever the procedure for reaching it, because it is not compatible with the right answer, with the moral truth the IACHR knows and just has to communicate to the State.

If the popular vote does not avoid mistakes, and the IACHR believes that the Uruguayan decision is mistaken because it is contrary to universal human values, what is at stake is a peculiar form of strong populism, in which the role of the real national people is played by humanity, and the role of the national populist leader is played by the court itself. The moral intuitions of human rights judges are hence functionally equivalent to the political intuitions of populist leaders.

In that case, the intervention of the regional court is clearly a threat to democracy, a threat that is even less justified when the democratic expression is clearly inclusive. Faced with such a threat, the emotive reaction can imply a strong populist and nationalist argument against foreign interferences. So, if populism can, in its own way, generate in liberal democrats some kind of fear, the anti-democratic interference of an RHRC - by making stronger the populist ressentiment - can increase such negative feeling and then threaten both the RHRC and (liberal) democracy.

\subsection{Universalizable Moral Prescriptions as the Rules of the Many}

In the previous paragraphs I analyzed the Gelman case on the basis of a double assumption: that the democratic process was not deliberative - even if it was clearly inclusive - and that the judicial answer was based on some descriptivist meta-ethic. What if, on both sides, the decision is just considered as a moral prescriptive conclusion and not as the unavoidable consequence of some moral truth?

\footnotetext{
${ }^{40}$ According to Landemore (2012a, p. 10), this is "because the more reliable knower is actually the group as a whole". This intuition is fully developed in Landemore 2012b.
} 
In what follows, I will focus on a trivial necessary condition for any deliberativist conception, but so minimalist that deliberativists would not accept such a condition as sufficient: the fact of exchanging arguments, the fact of the dialogue between opposite initial postures, needs and increases imagination. ${ }^{41}$ Whatever the final decision, the fact of taking the time and making the effort to understand others' minds is a strong argument for the acceptability of a moral argument. The need for making this effort is, in an important sense, a consequence of the distrust in moral intuitions. As Nietzsche said in the aphorism I quoted at the beginning, this effort is the best path when deep reasoners know that they are "always wrong".

As mentioned in section 4.3, imagination is a central ingredient of prescriptivism. To universalize a prescription for actual and hypothetical cases, it is fundamental to use imagination. In order to improve such cognitive ability, to feel empathy is essential. Without empathy, the imagination can be substantially limited.

According to Landemore's theory, a decision made by the Uruguayan people, even if non-deliberative, can be perceived as the better decision, not because of strong epistemic reasons but, humbly, because of the importance of cognitive diversity that, simply and incontestably, increases with number. ${ }^{42}$ Such cognitive diversity increases imagination, and can improve universalizing abilities, even if it does not necessarily improve moral epistemic abilities; it improves "the protean capacity to shift from preconscious reliance to deliberative process and back" (Marcus 2012, p. 166). That deliberation takes place or not, from this perspective, does not matter.

From a very skeptical perspective, the majority, understood as the half-plus-one of any group, would be the best placed for taking political decisions on moral matters, not because its deliberation is better than the elitist judicial deliberation, but because number makes it cognitively more diverse. My point here is that, if all the institutional actors renounce moral truths, there is no reason for not considering that the inclusion of supra-national judges can increase the cognitive diversity and thus produce better arguments.

Of course, this is true on one crucial condition: that judges do not have any pretension to be better at moral reasoning than demo-

\footnotetext{
${ }^{41}$ See, at least, Nino 1996 (p. 125): “The assumption of the moral point of view - the assumption of impartiality - requires putting ourselves in the place, or 'into the shoes', of fellow human beings, which involves the intellectual faculty of imagination and the emotional attribute of human sympathy."

${ }^{42}$ Landemore (2012b) borrows the notion of "cognitive diversity" from Hong and Page 2004.
} 
cratic bodies. If they renounce such pretension, they can improve the democratic moral reasoning and the political decision that is its natural outcome. To be skeptical does not necessarily mean to be relativist: the distrust in truth calls for institutions able to minimize the cost of mistakes, and to improve mechanisms for identifying this cost. The goal of such institutions would not be to "inform" about moral or political truths, but to contribute to the improvement of moral and political arguments.

Let me now return to an interpretation, under this light, of the Gelman case. Assuming that what the court said is that the decision of Uruguayan people was a mistake, it is possible to interpret such a strong and apparently descriptivist statement as the mere contribution to a finer assessment of the question at stake. ${ }^{43}$ Uruguayan people, in a possible world, could have been consulted on the same question but on the basis of the Gelman decision. It is possible that the same people who confirmed the Amnesty Law would change their minds because of the arguments provided by the court. Why? Because they would probably take into account the court's opinion, as an important element and as an ingredient for extending the understanding of actual and future cases. The condition for such change is that the question at stake is permanently left open, that the court's moral judgment is considered an acceptable argument for a prescription and not as a definitive truth.

\section{Conclusion}

In a nutshell: a potentially wrong majority decision could be, all things considered, the best decision and could have "a claim to compliance" (Estlund 2009, p. 20). In my opinion, the richness of Landemore's approach lies in her sui generis epistemic claim and in the rejection of "the classical divide between aggregative and deliberative democrats" (2012a, p. 9). ${ }^{44}$ As, in legal philosophy, some anti-positivist has replaced the thesis of a necessary connection between law and morals by a modest thesis according to which the law necessarily has a pretension to moral correctness (Alexy 1989), the finest epistemic theorists seem to accept that there is nothing to discover but, at the same time, we cannot justify democracy without

${ }^{43}$ Of course, it is not a very plausible interpretation, because the court did not make the argumentative effort that it should have in order to justify the irrelevance of popular vote.

${ }^{44}$ See too Føllesdall 2006. 
some belief in its capacity for reaching better (but not necessary the only right) decisions.

The real question is not who is the best moral reasoner or the best political decision-maker. The question, I suspect, is about how theorists reconstruct what moral and political actors do, when they construct arguments. And to talk of "best reasoners" is a dangerous ideological move. Any truth, moral or political, is a potential threat both to democracy and the RHRC. When we say that certain democratic or judicial actors are more competent for discovering the truth, we are weakening the authority of the supposedly less competent actor. By contrast, if we renounce any possibility of discovering the truth, all participants could make their contributions to reduce the risk of bad decisions, even if, in some cases, we - as individual moral reasoners - believe that one of them is right and the others are wrong.

My conclusive claim is that, by accepting a less (or not at all) epistemic version of a cognitive-diversity-oriented theory of democracy, it is not impossible to see, in the intervention of an RHRC, a form of increasing cognitive diversity and the quality of democracy. The key is to renounce the sterile (and threatening) opposition between the elitist judicial truth and the inclusive democratic truth in order to reconstruct the same situation as a potentially transnational weak deliberation, in which the inclusion of RHRCs not only increases the number of actors and their average moral competence, but, above all, improves the ability to make universalizable prescriptions; all of this, finally, makes our potentially bad arguments (and decisions) more acceptable.

\section{REFERENCES}

Alexy, Robert, 1989, "On Necessary Relations Between Law and Morality", Ratio Juris, vol. 2, no. 2, pp. 167-183.

Arditi, Benjamin, 2003, "Populism, or Politics at the Edges of Democracy", Contemporary Politics, vol. 9, no. 1, pp. 17-31.

Bandes, Susan A., 2012, "Emotion and Deliberation: The Autonomous Citizen in the Social World", in Fleming 2012, pp. 189-211.

Berezin, Mabel, 2002, "Secure States: Towards a Political Sociology of Emotion", in Jack Barbalet (ed.), Emotions and Sociology, Basil Blackwell, London, pp. 33-52.

Broad, C.D., 1930 (2000), Five Types of Ethical Theory, Routledge, London. 
Cowie, Roddy, Naomi Sussman, and Aaron Ben-Ze'ev, 2011, "Emotion: Concepts and Definitions", in Paolo Petta et al. (eds.), Emotion-Oriented Systems. The Humaine Handbook, Springer, Berlin, pp. 9-30.

Da Silva, Virgílio Afonso, 2013, "Deciding without Deliberating", International Journal of Constitutional Law, vol. 11, no. 3, pp. 557-584.

Damasio, Antonio R., 1999, The Feeling of What Happens: Body and Emotion in the Making of Consciousness, Harcourt Brace, San Diego.

Dancy, Jonathan, 2004, Ethics without Principles, Clarendon Press, Oxford.

Darwall, Stephen, 2003, "Moore, Normativity, and Intrinsic Value", Ethics, vol. 113, pp. 468-489.

Demertzis, Nicolas, 2006, "Emotions and Populism", in Simon Clarke et al. (eds.), Emotion, Politics and Society, Palgrave Macmillan, New York, pp. 103-122.

De Mesel, Benjamin, 2016, "How Morality Can Be Absent from Moral Arguments", Argumentation, vol. 30, no. 4, pp. 443-463.

Deight, John, 2011, "Empathy, Justice, and Jurisprudence", The Southern Journal of Philosophy, vol. 49, pp. 73-90.

Dworkin, Ronald, 2011, Justice for Hedgehogs, Harvard University Press, Cambridge, Mass.

— 1985, A Matter of Principle, Harvard University Press, Cambridge, Mass.

Dyzenhaus, David, 2009, “Are Legislatures Good at Morality? Or Better at It than the Courts?", International Journal of Constitutional Law, vol. 7, no. 1 , pp. 46-52.

Estlund, David, 2009, "Epistemic Proceduralism and Democratic Authority", in Ronald Tinnevelt and Raf Geenens (eds.), Does Truth Matter? Democracy and Public Space, Springer, Berlin, pp. 15-27.

—_, 2008, Democratic Authority: A Philosophical Framework, Princeton University Press, Princeton.

Feteris, Eveline T., 2016, "Prototypical Argumentative Patterns in a Legal Context: The Role of Pragmatic Argumentation in the Justification of Judicial Decisions", Argumentation, vol. 30, no. 1, pp. 61-79.

Fleming, James E. (ed.), 2012, Passions and Emotions: Nomos LIII, New York University Press, New York.

Føllesdall, Andreas, 2006, "The Value Added by Theories of Deliberative Democracy. Where (Not) to Look", in Samantha Besson and José Luis Martí (eds.), Deliberative Democracy and its Discontents, Routledge, New York.

Fullinwider, Robert K., 1977, "Fanaticism and Hare's Moral Theory", Ethics, vol. 87, no. 2, pp. 165-173.

Gargarella, Roberto, 2015, "La democracia frente a los crímenes masivos: una reflexión a la luz del caso Gelman", Revista Latinoamericana de Derecho Internacional, vol. 2, pp. 1-15; available at: <http://www. revistaladi.com.ar/numero2-gargarella/ $>$ [accessed: 26/12/2016]. 
Gilbert, Michael A., 2004, "Emotion, Argumentation and Informal Logic", Informal Logic, vol. 24, no. 3, pp. 245-264.

Gonzalez Bertomeu, Juan Francisco, 2011, "Against the Core of the Case: Structuring the Evaluation of Judicial Review", Legal Theory, vol. 17, no. 2, pp. 81-118.

Greene, Jamal, 2013, "Pathetic Argument in Constitutional Law", Columbia Law Review, vol. 113, no. 6, pp. 1389-1481.

Greppi, Andrea, 2013, "Concepciones epistémicas y concepciones doxásticas de la democracia", Eunomía, vol. 4, pp. 42-72.

Hare, Richard M., 1963, Freedom and Reason, Oxford University Press, Oxford.

—, 1952, The Language of Morals, Oxford University Press, Oxford.

Hart, H.L.A., 1977 (1983), “American Jurisprudence Through English Eyes: the Nightmare and the Noble Dream", Essays in Jurisprudence and Philosophy, Clarendon Press, Oxford, pp. 123-158.

Hong, Lu, and Scott Page, 2004, "Groups of Diverse Problem Solvers Can Outperform Groups of High-Ability Problem Solvers", Proceedings of the National Academy of Sciences, vol. 101, no. 46, pp. 16385-16389.

James, William M., 1879, "The Sentiment of Rationality", Mind, vol. 4, no. 15 , pp. 317-346.

Landemore, Hélène, 2012a, "Why the Many Are Smarter than the Few and Why It Matters", Journal of Public Deliberation, vol. 8, no. 1; available at: <http://www.publicdeliberation.net/jpd/vol8/issl/art7> [accessed: $26 / 12 / 2016]$.

- 2012b, Democratic Reason: Politics, Collective Intelligence, and the Rule of the Many, Princeton University Press, Princeton.

Landemore, Hélène, and Hugo Mercier, 2012, "Reasoning is for Arguing: Understanding the Successes and Failures of Deliberation", Political Psychology, vol. 33, no. 2, pp. 243-258.

Marcus, George E., 2012, "Reason, Passion, and Democratic Politics: Old Conceptions-New Understandings_-New Possibilities", in Fleming 2012, pp. 127-188.

Mohammed, Dima, 2016, "Goals in Argumentation: A Proposal for the Analysis and Evaluation of Public Political Arguments", Argumentation, vol. 30, pp. 221-245.

Moore, George E., 1903, Principia Ethica, Cambridge University Press, Cambridge.

Nelissen, Rob M.A., Seger M. Breugelmans, and Marcel Zeelenberg, 2013, "Reappraising the Moral Nature of Emotions in Decision Making: The Case of Shame and Guilt", Social and Personality Psychology Compass, vol. 7, pp. 355-365.

Nino, Carlos S., 1996, The Constitution of Deliberative Democracy, Yale University Press, New Haven.

—_, 1984, Introducción al análisis del derecho, Astrea, Barcelona. 
Puppo, Alberto, 2016, "Reasonable Stability vs. Radical Indeterminacy: a Disanalogy between Domestic Rule of Law and Humanity-Based International Law", Revus - Journal for Constitutional Theory and Philosophy of Law, vol. 30, pp. 81-102.

Robinson, H.M., 1981, "Imagination, Desire and Prescription", Analysis, vol. 41, no. 1, pp. 55-59.

Sadurski, Wojciech, 2009, "Rights and Moral Reasoning: An Unstated Assumption-A Comment on Jeremy Waldron's 'Judges as Moral Reasoners", International Journal of Constitutional Law, vol. 7, no. 1, pp. 25-45.

Saffon, Maria Paula, and Nadia Urbinati, 2013, "Procedural Democracy, the Bulwark of Equal Liberty", Political Theory, vol. 41, no. 3, pp. 441-481. Sajó, András, 2016, "Emotions in Constitutional Institutions", Emotion Review, vol. 8, no. 1, pp. 44-49.

— , 2010, "Emotions in Constitutional Design", International Journal of Constitutional Law, vol. 8, no. 3, pp. 354-384.

Sidgwick, Henry, 1906, The Methods of Ethics, 7th ed. [1st ed. 1874], Macmillan and Company, London.

Van den Hoven, Paul, 2011, "The Unchangeable Judicial Formats", Argumentation, vol. 25, no. 4, pp. 499-511.

Van Eemeren, Frans H., Bart Garssen, and Bert Meuffels, 2012, "Effectiveness through Reasonableness: Preliminary Steps to Pragma-Dialectical Effectiveness Research", Argumentation, vol. 26, no. 1, pp. 33-53.

Waldron, Jeremy, 2009a, "Judges as Moral Reasoners", International Journal of Constitutional Law, vol. 7, no. 1, pp. 2-24.

— 2009b, "Refining the Question About Judges' Moral Capacity", International Journal of Constitutional Law, vol. 7, no. 1, pp. 69-82.

White, Emily Kidd, 2014, "Till Human Voices Wake Us: The Role of Emotions in the Adjudication of Dignity Claims", Journal of Law, Religion and State, vol. 3, no. 3, pp. 201-239.

Received: June 5, 2017; revised: March 23, 2018; accepted: April 12, 2018. 